\title{
Reduction of Cationic Free-Base meso-Tris- $N$-Methylpyridinium-4-yl Porphyrins in Positive Mode Electrospray Ionization Mass Spectrometry
}

\author{
Catarina I. V. Ramos, and M. Graça Santana Marques, \\ and A. J. Ferrer Correia \\ Mass Spectrometry Laboratory, Department of Chemistry, University of Aveiro, Campus de Santiago, \\ Aveiro, Portugal \\ Vanda Vaz Serra, João P. C. Tomé, Augusto C. Tomé, \\ M. Graça P. M. S. Neves, and J. A. S. Cavaleiro \\ Organic Chemistry Laboratory, Department of Chemistry, University of Aveiro, Campus de Santiago, \\ Aveiro, Portugal
}

\begin{abstract}
Reductions involving more than one electron with formation of the $\mathrm{M}^{+}$and $[\mathrm{M}+2 \mathrm{H}]^{+}$ions were observed for electrosprayed meso-tris( $N$-methylpyridinium-4-yl)porphyrin iodides, $\mathrm{MI}_{3}$. These reductions were studied by using different solvents and flow rates. Formation of the $[\mathrm{M}+2 \mathrm{H}]^{+}$ions occurred only for protic solvents and to a larger extent at lower flow rates. The type of the fourth substituent does not seem to affect the reduction processes. Formation of the two reduced species, $\mathrm{M}^{+}$and $[\mathrm{M}+2 \mathrm{H}]^{+}$ions, may occur through the participation of counter ion/solvent clusters. Reduction of multiply charged, non-metallated species with formation of $[\mathrm{M}+n \mathrm{H}]^{+}$ions $(n>1)$ was not observed before in positive mode electrospray mass spectrometry. (J Am Soc Mass Spectrom 2007, 18, 762-768) (C) 2007 American Society for Mass Spectrometry
\end{abstract}

$\mathrm{T}$ The electrolytic nature of some processes occurring in electrospray interfaces was postulated a decade ago $[1,2]$ and, notwithstanding some controversy [3], it is generally accepted that redox reactions do occur in the capillary sprayers and that they are responsible for charge balance [1,2]. Redox processes in electrospray mass spectrometry were comprehensively investigated by Van Berkel and collaborators [4-8] and, more recently, electrochemical aspects and applications of electrospray ionization were the focus of reviews $[9,10]$.

Ions formed by one electron reduction from nonmetallated dicationic species in solution were previously observed in positive-mode electrospray mass spectrometry for ionic compounds such as diquaternary pyridinium salts [11-13] and free-base $\mathrm{N}$-alkylpyridiniumyl porphyrin salts [14]. One- and two-electron reductions of the cations of metallated $\mathrm{N}$-alkylpyridiniumyl porphyrin salts were also reported, when electrospray was used in the positive mode [15-17].

Published online February 12, 2007

Address reprint requests to Dr. M. Graça Santana Marques, Department of Chemistry, University of Aveiro, Campus de Santiago, 3810-193 Aveiro, Portugal. E-mail: grmarques@dq.ua.pt
When acquiring the electrospray mass spectra of 5,10,15-tris( $N$-methyl-pyridinium-4-yl)-20-phenylporphyrin iodide, $\mathrm{MI}_{3}$, we observed, besides the expected $\mathrm{M}^{3+}$ ion, ions such as $\mathrm{M}^{2+}, \mathrm{M}^{+}$, and $[\mathrm{M}+2 \mathrm{H}]^{+}$, which may be the result of reductive processes. Reductions involving more than one electron were never reported before for electrosprayed free-base cationic porphyrins and, although formation of $[\mathrm{M}+n \mathrm{H}]^{+}$ions $(n>1)$ in desorption ionization (fast atom or ion bombardment) [18-20] and matrix assisted laser desorption (MALDI) [21] has been described, it was never reported as occurring in electrospray mass spectrometry (ESI-MS) until now. These facts prompted us to use ESI-MS to investigate a group of meso-tris( $N$-methylpyridinium-4yl)porphyrin iodides, $\mathrm{MI}_{3}$, with a different fourth meso substituent (see Scheme 1) to gather more information on the species formed with respect to their formation reactions and to their relation with the ionization processes occurring in the electrospray interface.

\section{Experimental}

The key neutral porphyrin derivatives were obtained from crossed-Rothemund reactions using the appropriate benzaldehydes and pyrrole in refluxing acetic acid and nitrobenzene [22-24]. The alkylation with methyl 


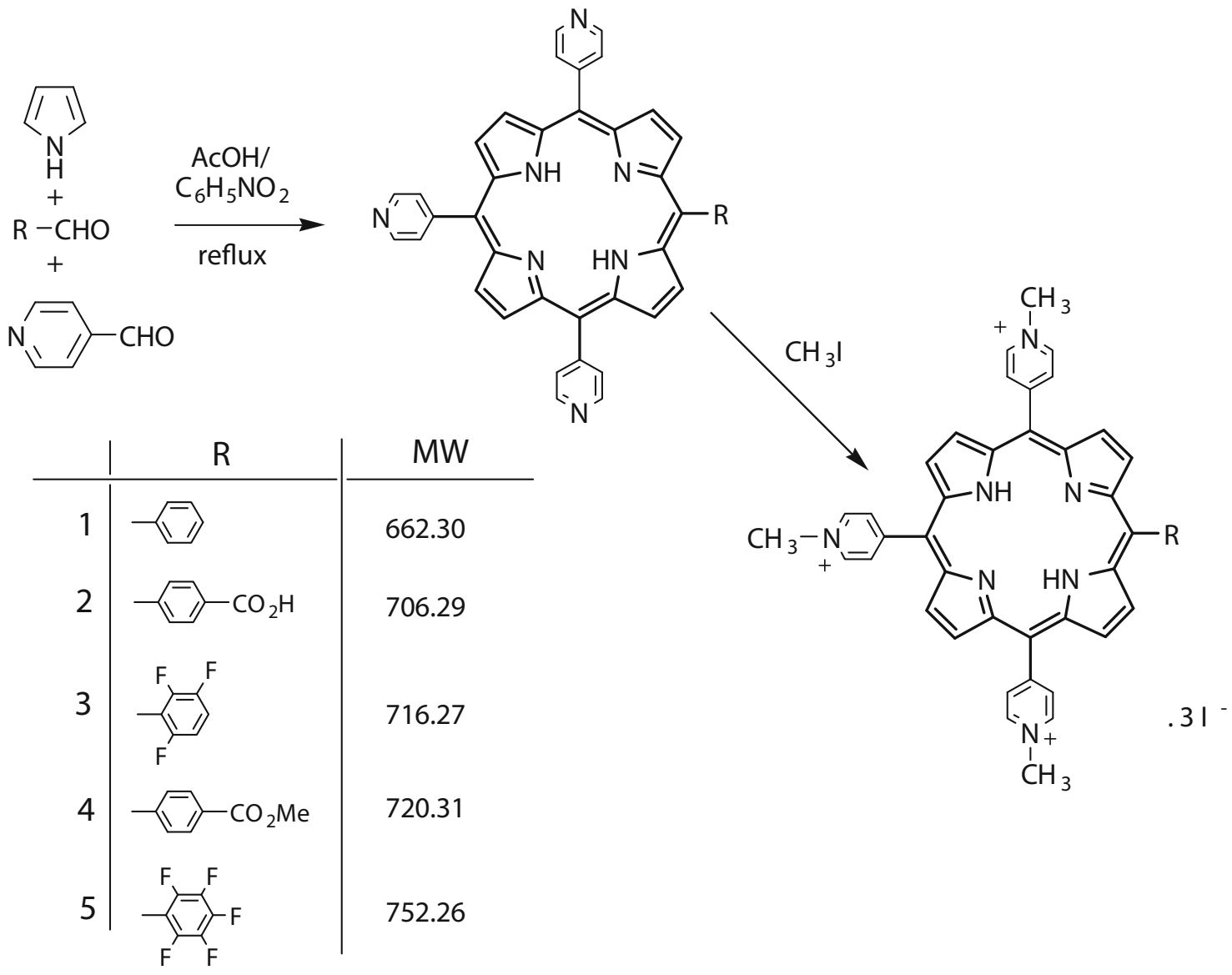

Scheme 1

iodide in dry DMF (dimethylformamide) gave the expected tris( $N$-methylpyridinium)porphyrin salts 1-5 in roughly 95\% yield (Scheme 1) [23].

The porphyrin iodides were characterized by nuclear magnetic resonance (NMR) ${ }^{1} \mathrm{H},{ }^{19} \mathrm{~F}$, and ${ }^{13} \mathrm{C}$, elemental analysis, and ultraviolet-visible (UV-Vis) spectroscopy.

UV-Vis absorption spectra were obtained using a Uvikon 922 spectrophotometer (Kontron Instruments Ltd., Hertfortshire, UK) and scanning from 350 to $800 \mathrm{~nm}$; a 1-cm path length cuvette was used in all experiments. For the UV-Vis measurements, solutions about $10^{-5} \mathrm{M}$ of the porphyrins in methanol were used.

ESI mass spectra were acquired with a Micromass Q-Tof 2 (Micromass, Manchester, UK), operating in the positive mode, equipped with a Z-spray source, an electrospray probe, and a syringe pump. Source and desolvation temperatures were 80 and $150{ }^{\circ} \mathrm{C}$, respectively. Capillary voltage was $3000 \mathrm{~V}$. The spectra were acquired at a nominal resolution of 9000 and at cone voltages between 30 and $50 \mathrm{~V}$ (mostly at $30 \mathrm{~V}$ ). Nebulization and collision gases were $\mathrm{N}_{2}$ and $\mathrm{Ar}$, respectively. Porphyrin solutions were prepared at about 0.86 , 1.7 , and $3.5 \mu \mathrm{M}$ concentrations in a variety of solvents (methanol, 1\% vol/vol $N, N$ dimethylaniline in methanol, acetonitrile, and $\mathrm{D}_{4}$-methanol). Sample flow rates

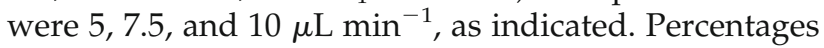

of the total ion current (\%TIC) for selected ions of the spectra were determined by averaging the spectra for 0.8 to $2 \mathrm{~min}$ of the acquisition time, after sample injection. The pusher frequency recorded was 22,727 $\mathrm{Hz}$.

Product-ion spectra were acquired by selecting the precursor ions with the quadrupole and using the hexapole as collision cell with energies from 20 to $50 \mathrm{eV}$.

\section{Results and Discussion}

\section{Electrospray Mass Spectrometry Using Methanol}

ESI mass spectra. In the ESI mass spectra of all the meso-tris(N-methylpyridium-4-yl)porphyrin iodide, $\mathrm{MI}_{3}$, peaks corresponding to the $\mathrm{M}^{3+}, \mathrm{M}^{2+}$, and $[\mathrm{M}-\mathrm{H}]^{2+}$ ions are observed. For higher concentrations and higher flow rates the base peaks correspond to the $\mathrm{M}^{3+}$ ions; the second most abundant ions are the $\mathrm{M}^{2+}$ ions. Singly charged ions corresponding to $\mathrm{M}^{+}$and $[\mathrm{M}+2 \mathrm{H}]^{+}$are also observed. Peaks corresponding to the formation of ion clusters, such as $\left[\mathrm{M}^{3+}+2 \mathrm{I}^{-}\right]^{+}$and $\left[\mathrm{M}^{3+}+\mathrm{I}^{-}\right]^{2+},{ }^{\circ}$ are $^{\circ}$ not $^{\circ}$ observed. ${ }^{\circ} \operatorname{In}^{\circ}$ Figure $^{\circ} 1^{\circ}$ the ${ }^{\circ}$ mass spectrum of compound $\mathbf{1}$ is shown (concentration $3.5 \times$ $10^{-6} \mathrm{M}$, flow rate $10 \mu \mathrm{L} \mathrm{m^{-1 }}{ }^{-}$. The experimental and calculated isotopic patterns of the $\mathrm{M}^{+}$and $[\mathrm{M}+2 \mathrm{H}]^{+}$ 


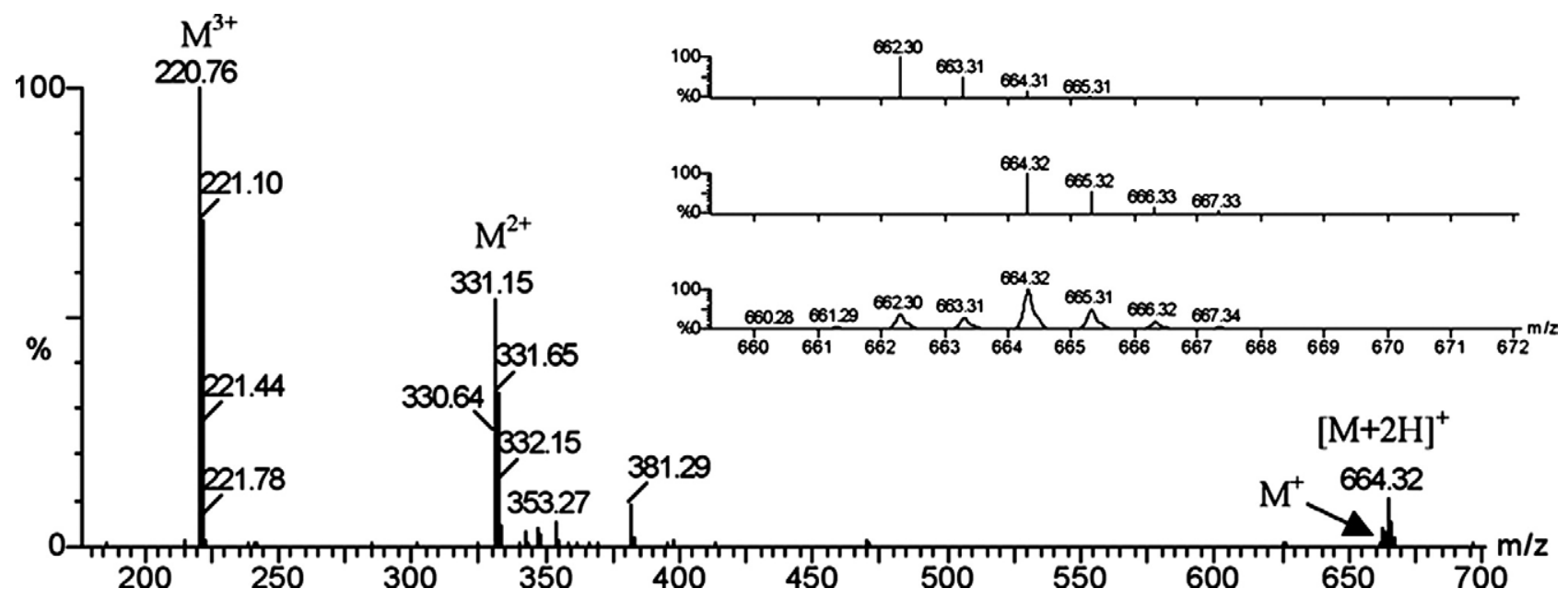

Figure 1. Mass spectrum of compound 1: (a) calculated isotopic pattern of the $\mathrm{M}^{+}$ion; (b) calculated isotopic pattern of the $[\mathrm{M}+2 \mathrm{H}]^{+}$ion; (c) observed experimental pattern of the $\mathrm{M}^{+}$and $[\mathrm{M}+2 \mathrm{H}]^{+}$ions.

ions are also shown. It is apparent from the figure that, in the singly charged experimental cluster, the most abundant peak may be attributed to the $[\mathrm{M}+2 \mathrm{H}]^{+}$ion.

The relative abundance of the $[\mathrm{M}+2 \mathrm{H}]^{+}$ions increases dramatically at lower flow rates for the solutions with higher and intermediate concentrations. In Table ${ }^{\circ} 1^{\circ}$ the ${ }^{\circ}$ abundances ${ }^{\circ}$ of ${ }^{\circ}$ the ${ }^{\circ} \mathrm{M}^{+^{\circ}}$ and ${ }^{\circ}[\mathrm{M}+2 \mathrm{H}]^{+}{ }^{\circ}$ ions (expressed by the average of triplicate measurements of the percentage of the TIC) for several concentrations and flow rates, for compound 1, using methanol as a solvent, are presented. The spectra were acquired at a cone voltage of $30 \mathrm{~V}$.

The abundance of both ions increases with increasing concentration, especially the abundance of the $[\mathrm{M}+2 \mathrm{H}]^{+}$ions. The substitution of a phenyl group by aryl groups with electron-withdrawing substituents $(2,3,6-$ trifluorophenyl, pentafluorophenyl, 4-carboxyphenyl, and 4-methoxycarbonylphenyl) does not significantly affect the abundance of the reduced species $\mathrm{M}^{2+}, \mathrm{M}^{+}$, and $[\mathrm{M}+2 \mathrm{H}]^{+}$.

Product-ion spectra. Product-ion spectra were acquired for selected ions using methanol as the eluent, for solutions $3.5 \times 10^{-6} \mathrm{M}$ and flow rates of $10 \mu \mathrm{L} \mathrm{min}^{-1}$. When the precursor ions were the $\mathrm{M}^{3+}, \mathrm{M}^{2+}$, and $\mathrm{M}^{+}$ ions, the cone voltage and collision energy used were, respectively, $30 \mathrm{~V}$ and $25 \mathrm{eV}$. When the precursor ions were the $[\mathrm{M}+2 \mathrm{H}]^{+}$ions, the cone voltage and collision energy ${ }^{\circ}$ used ${ }^{\circ}$ were, respectively, ${ }^{\circ} 0^{\circ} \mathrm{V}$ and $45^{\circ} \mathrm{eV}$. In Table $2^{\circ}$ the $e^{\circ}$ product-ion ${ }^{\circ}$ spectra ${ }^{\circ}$ of ${ }^{\circ}$ the ${ }^{\circ} \mathrm{M}^{3+}{ }^{\circ}$ and $^{\circ} \mathrm{M}^{2+}{ }^{\circ}$ ions ${ }^{\circ}$ are summarized.

The fragmentation of the $\mathrm{M}^{3+}$ and $\mathrm{M}^{2+}$ ions for all the porphyrins studied occurs predominantly through radical losses from the substituent groups of the macrocycle, with formation of triply and doubly charged product ions, respectively. For the same experimental parameters the relative abundances of the $\mathrm{M}^{3+}$ precursor ions are higher than the relative abundance of the corresponding $\mathrm{M}^{2+}$ precursor ions. The $\mathrm{M}^{2+}$ ions frag- ment mostly through one single channel-loss of one methyl radical, leading to the $\left[\mathrm{M}-\mathrm{CH}_{3}\right]^{2+}$ ions. The formation of doubly charged product ions from the $\mathrm{M}^{3+}$ precursors, and of singly charged product ions from the $\mathrm{M}^{2+}$ precursors, may be ascribed to charge separation, through either loss of the elements of one methylpyridiniumyl cation plus loss of other radicals $\left(\mathrm{H}, \mathrm{CH}_{3}\right)$ or loss of one methyl cation plus the elements of one methylpyridiniumyl radical, plus other radicals.

Similarly to the $\mathrm{M}^{2+}$ ions, the $\mathrm{M}^{+}$ions fragment mostly through one single channel, losing a $30-\mathrm{Da}$ neutral fragment, with formation of species to which the $\left[\mathrm{M}-2 \mathrm{CH}_{3}\right]^{+}$composition may be ascribed. The second most abundant species are formed by loss of one methyl radical.

The $\mathrm{M}^{2+}$ ions may be formed by one electron reduction of the $\mathrm{M}^{3+}$ ions and are probably hypervalent radicals. Detection of similar hypervalent radicals formed by one electron reduction of quaternary ammonium (and phosphonium) salts in the gas phase, by using several mass spectrometric techniques, has been known ${ }^{\circ}$ since $^{\circ} 1980^{\circ}[25]^{\circ}$ and $^{\circ}$ is ${ }^{\circ}$ extensively ${ }^{\circ}$ documented

Table 1. Abundances of the $\mathrm{M}^{+}$and $[\mathrm{M}+2 \mathrm{H}]^{+}$ions (\%TIC)

\begin{tabular}{cccc}
\hline & & \multicolumn{2}{c}{ Average (\%SD) } \\
\cline { 3 - 4 } Concentration & \begin{tabular}{c} 
Flow \\
\cline { 3 - 4 }$\left(\mu \mathrm{L} / \mathrm{min}^{-1}\right)$
\end{tabular} & $\mathrm{M}^{+}(\% \mathrm{TIC})$ & {$[\mathrm{M}+2 \mathrm{H}]^{+}(\% \mathrm{TIC})$} \\
\hline \hline $8.6 \times 10^{-7} \mathrm{M}$ & 5 & $0.1(9)$ & $3(14)$ \\
& 7.5 & $0.1(6)$ & $3(14)$ \\
$1.7 \times 10^{-6} \mathrm{M}$ & 10 & $0.2(6)$ & $3(24)$ \\
& 5 & $0.8(12)$ & $19(5)$ \\
$3.5 \times 10^{-6} \mathrm{M}$ & 7.5 & $1(13)$ & $11(15)$ \\
& 5 & $1(7)$ & $8(15)$ \\
& 7.5 & $2(15)$ & $37(9)$ \\
& 10 & $3(7)$ & $33(8)$ \\
& & $3(9)$ & $14(14)$ \\
\hline
\end{tabular}

Note: \%SD, percentage standard deviation; \%TIC, percentage total ion current. 
Table 2. Product-ion spectra of the $\mathrm{M}^{3+}$ and $\mathrm{M}^{2+}$ ions $(\mathrm{m} / \mathrm{z}$, \%RA)

\begin{tabular}{llccrc}
\hline & \multicolumn{5}{c}{ Compound } \\
\cline { 2 - 5 } Fragment composition & $\mathbf{1}$ & $\mathbf{2}$ & $\mathbf{3}$ & $\mathbf{4}$ & $\mathbf{5}$ \\
\hline \hline$[\mathrm{M}]^{3+}$ (precursor ion) & $\mathbf{2 2 0 . 7 6 ( 1 0 0 )}$ & $\mathbf{2 3 5 . 4 4 ( 1 0 0 )}$ & $\mathbf{2 3 8 . 7 4 ( 1 0 0 )}$ & $\mathbf{2 4 0 . 1 1 ( 1 0 0 )}$ & $\mathbf{2 5 0 . 7 5 ( 1 0 0 )}$ \\
{$\left[\mathrm{M}-\mathrm{CH}_{3}\right]^{3+}$} & $215.83(50)$ & $230.40(14)$ & $233.74(33)$ & $235.11(20)$ & $245.75(45)$ \\
{$\left[\mathrm{M}-\mathrm{R}-\mathrm{CH}_{3}\right]^{3+}$} & $190.08(20)$ & $190.08(11)$ & $190.07(19)$ & $190.08(14)$ & $190.08(44)$ \\
{$[\mathrm{M}-\mathrm{R}]^{3+}$} & $195.09(14)$ & $195.09(9)$ & $195.07(6)$ & $195.09(26)$ & $195.09(32)$ \\
{$\left[\mathrm{M}-\mathrm{C}_{6} \mathrm{H}_{7} \mathrm{~N}-\mathrm{CH}_{3}\right]^{2+}$} & $277.11(42)$ & $299.10(15)$ & $304.08(19)$ & $306.12(42)$ & $322.09(57)$ \\
{$\left[\mathrm{M}-\mathrm{C}_{6} \mathrm{H}_{7} \mathrm{~N}\right]^{2+}$} & $284.64(50)$ & $306.66(13)$ & $311.61(10)$ & $313.66(27)$ & $329.62(40)$ \\
{$[\mathrm{M}]^{2+}(\mathrm{precursor}$ ion) } & $\mathbf{3 3 1 . 1 5}(0.8)$ & $\mathbf{3 5 3 . 0 9 ( 8 . 8 )}$ & $\mathbf{3 5 8 . 1 2 ( 0 . 9 )}$ & $\mathbf{3 6 0 . 1 4}(3.8)$ & $\mathbf{3 7 6 . 1 2 ( 1 . 7 )}$ \\
{$\left[\mathrm{M}-\mathrm{CH}_{3}\right]^{2+}$} & $323.64(100)$ & $345.57(100)$ & $350.61(100)$ & $352.63(100)$ & $368.62(100)$ \\
$\left.[\mathrm{M}-2 \mathrm{CH}]_{3}\right]^{2+}$ & $316.15(7.0)$ & $338.09(5.3)$ & $343.12(5.0)$ & $345.14(4.0)$ & $361.12(5.0)$ \\
{$\left[\mathrm{M}-2 \mathrm{H}-\mathrm{C}_{6} \mathrm{H}_{7} \mathrm{~N}\right]^{+}$} & $567.23(0.3)$ & $613.25(1.9)$ & $621.17(0.2)$ & $625.21(0.4)$ & $657.19(0.9)$ \\
{$\left[\mathrm{M}-\mathrm{H}-\mathrm{C}_{6} \mathrm{H}_{7} \mathrm{~N}-\mathrm{CH}_{3}\right]^{+}$} & $553.22(3.0)$ & $597.21(3.3)$ & $607.16(1.2)$ & $611.2(1.3)$ & $643.18(4.0)$ \\
{$\left[\mathrm{M}-\mathrm{H}-\mathrm{C}_{6} \mathrm{H}_{7} \mathrm{~N}-2 \mathrm{CH}_{3}\right]^{+}$} & $538.19(1.7)$ & $582.17(1.7)$ & $592.14(0.7)$ & $596.17(0.5)$ & $628.16(1.4)$ \\
\hline
\end{tabular}

$\left[11,912,26^{\circ}-32\right] .{ }^{\circ}$ Contrary $9{ }^{\circ}{ }^{\circ}$ aliphatic ${ }^{\circ}$ ammonium hypervalent radicals that are transient species, aromatic ammonium hypervalent radicals are stabilized by partial delocalization of the electronic density throughout the macrocycle. Loss of one methyl group from the $\mathrm{M}^{2+}$ ions may lead to the formation of an even-electron doubly charged species with formation of a neutral pyridine substituent group.

Similarly, formation of the $\mathrm{M}^{+}$ions may occur by two electron reduction of $\mathrm{M}^{3+}$ and the former are probably a cationic porphyrin with two neutral hypervalent nitrogens. Two electron reductions were never reported before for free-base cationic porphyrins or other organic cations when using electrospray mass spectrometry.

The most abundant product ions of the $[\mathrm{M}+2 \mathrm{H}]^{+}$ ions are, as in the case of the $\mathrm{M}^{+}$ions, formed by a 30-Da neutral loss, arising from the loss of two methyl radicals, with formation of the $\left[(\mathrm{M}+2 \mathrm{H})-2 \mathrm{CH}_{3}\right]^{+}$ions. The second most abundant product ions are the $\left[(\mathrm{M}+2 \mathrm{H})-\mathrm{CH}_{3}\right]^{+}$ions. Losses of the elements of one methylpyridiniumyl substituent and losses of the elements of one methylpyridiniumyl plus one and two methyl groups are also observed. At lower $\mathrm{m} / \mathrm{z}$ values, low abundant doubly and triply charged species are observed, respectively: the $\left[\mathrm{M}-\mathrm{CH}_{3}\right]^{2+}$ and $\mathrm{M}^{3+}$ ions. In Figure 2 the partial product-ion ${ }^{\circ}$ spectra of ${ }^{\circ}$ the $\left.9 \mathrm{M}+2 \mathrm{H}\right]^{+}$ ions of compounds 2,3 , and 4 , acquired at the same cone voltages and collision energies, are presented for $\mathrm{m} / \mathrm{z}$ values $>580$.

Reduction of the cationic $\mathrm{M}^{3+}$ porphyrins to the $[\mathrm{M}+2 \mathrm{H}]^{+}$species must involve hydrogen addition and multielectron reduction, leading to the corresponding dihydroporphyrins (also known as chlorins). If the $[\mathrm{M}+2 \mathrm{H}]^{+}$ions (and the $\mathrm{M}^{+}$ions) are hypervalent diradical species, the predominant loss of $30 \mathrm{Da}$ observed for both could lead to the formation of two neutral pyridine functions (see Scheme 2 for the $[\mathrm{M}+2 \mathrm{H}]^{+}$ions).

Observation of the $[\mathrm{M}+2 \mathrm{H}]^{+}$ions could be attributable either to chlorin contamination of the porphyrin samples or to an unlikely solution reduction (instantaneous upon dissolution, or overnight). These hypotheses were ruled out through acquisition of the UVvisible spectra of methanol solutions of the porphyrins, freshly prepared, and after $24 \mathrm{~h}$. No significant alter-

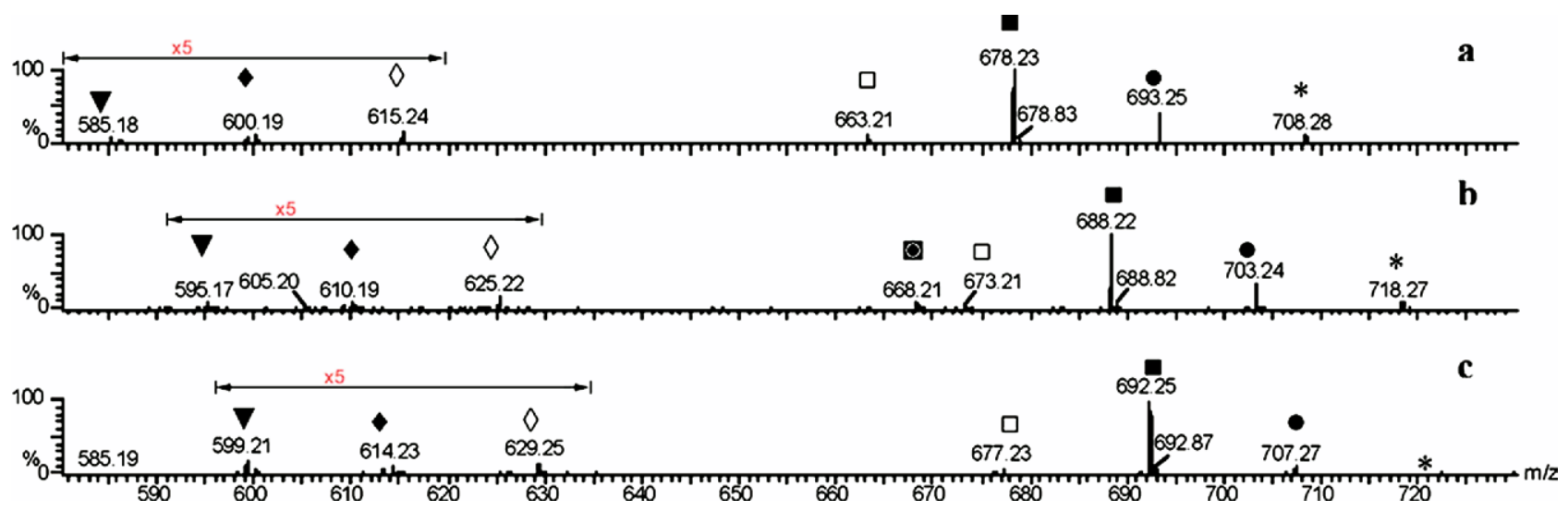

Figure 2. Product ion spectra of the $[\mathrm{M}+2 \mathrm{H}]^{+}$ions: (a) of compound 2; (b) of compound 3; (c) of compound 4. Legend: $*$, precursor ion $[\mathrm{M}+2 \mathrm{H}]^{+} ; \boldsymbol{\bullet},\left[(\mathrm{M}+2 \mathrm{H})-\mathrm{CH}_{3}\right]^{+} ; \mathbf{\square},\left[(\mathrm{M}+2 \mathrm{H})-2 \mathrm{CH}_{3}\right]^{+} ; \mathrm{Q}$ $\left[(\mathrm{M}+2 \mathrm{H})-\mathrm{HF}-2 \mathrm{CH}_{3}\right]^{+} ; \square,\left[(\mathrm{M}+2 \mathrm{H})-3 \mathrm{CH}_{3}\right]^{+} ; \diamond,\left[(\mathrm{M}+2 \mathrm{H})-\mathrm{C}_{6} \mathrm{H}_{7} \mathrm{~N}\right]^{+} ; \diamond,\left[(\mathrm{M}+2 \mathrm{H})-\mathrm{C}_{6} \mathrm{H}_{7} \mathrm{~N}-\mathrm{CH}_{3}\right]^{+} ; \boldsymbol{\nabla}$, $\left[(\mathrm{M}+2 \mathrm{H})-\mathrm{C}_{6} \mathrm{H}_{7} \mathrm{~N}-2 \mathrm{CH}_{3}\right]^{+}$. 


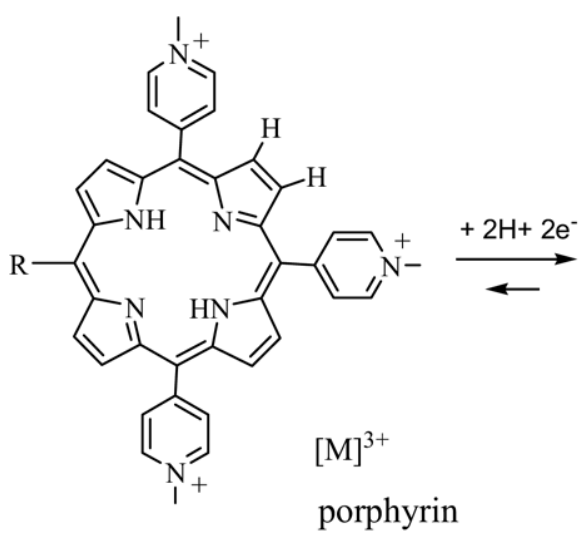

porphyrin

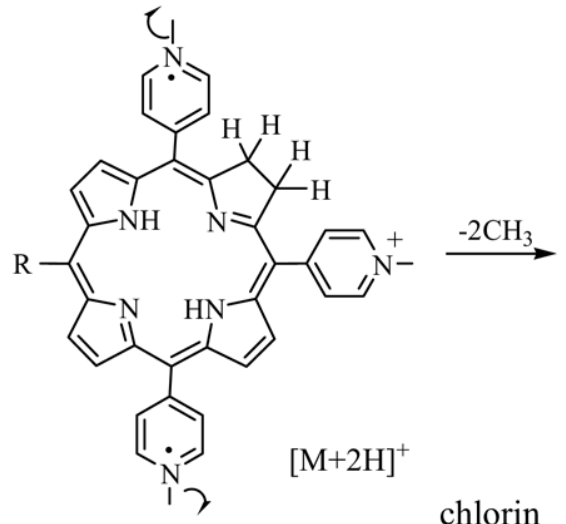

chlorin

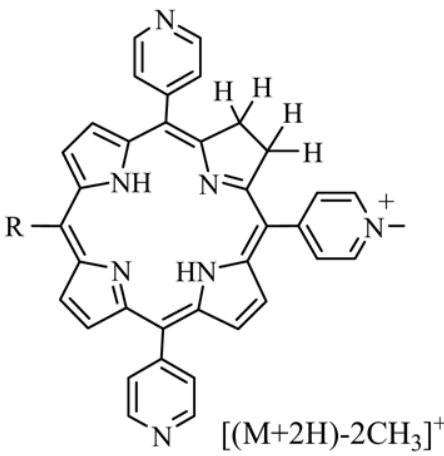

$\left[(\mathrm{M}+2 \mathrm{H})-2 \mathrm{CH}_{3}\right]^{+}$

Scheme 2

ations in the fourth $\mathrm{Q}$ band (fourth satellite band of the Sore ${ }^{\circ}$ or $^{\circ} \mathrm{B}^{\circ}$ band $)^{\circ}\left[33,{ }^{\circ} 34\right]^{\circ}$ were $^{\circ}$ detected $^{\circ}$ that ${ }^{\circ}$ could $^{\circ}$ be ascribed to the presence of the chlorins.

Reduction reactions in the metal capillary sprayers of mass spectrometers operating in the negative mode are an important step in the overall ionization process, being responsible for charge balance, but in the positive

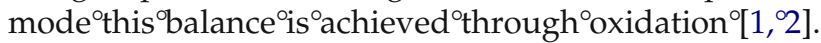
Thus the reductions that we observed in positive-mode electrospray, for the analytes studied, cannot be direct needle-induced redox reactions of the analytes, and the formation of the $\mathrm{M}^{+}$and $[\mathrm{M}+2 \mathrm{H}]^{+}$ions must occur, either previously in the solution, or after the migration through the needle. Nevertheless, direct solvent oxidation in the needle may be a plausible contributor to the overall redox process.

\section{ESI Mass Spectra and Product ion Spectra in Other Solvents}

Additional information was gathered by acquiring the spectra using other solvents: a mixture of methanol and an electron donor, $N, N$ dimethylaniline; an aprotic solvent, acetonitrile; and deuterated methanol. When methanol with added dimethylaniline was used, no significant differences were detected in the ESI mass spectra. When using acetonitrile $\mathrm{CH}_{3} \mathrm{CN}$, although the $\mathrm{M}^{2+}$ and $\mathrm{M}^{3+}$ ions were observed, the $[\mathrm{M}+2 \mathrm{H}]^{+}$ions were not.

The absence of the $[\mathrm{M}+2 \mathrm{H}]^{+}$ions when acetonitrile was used is indicative of the participation of methanol (a protic solvent) on their formation; thus the experiments were repeated using deuterated methanol $\mathrm{CD}_{3} \mathrm{OD}$. When the latter was used peaks corresponding to the triply charged $[\mathrm{M}-2 \mathrm{H}+2 \mathrm{D}]^{3+}$ ions; the doubly charged $\mathrm{M}^{2+}$ and $[\mathrm{M}-2 \mathrm{H}+2 \mathrm{D}]^{2+}$ ions; and the singly charged $\mathrm{M}^{+},[\mathrm{M}-\mathrm{H}+\mathrm{D}]^{+}$, and $[(\mathrm{M}-2 \mathrm{H}+2 \mathrm{D})+2 \mathrm{D}]^{+}$ions, whose formation may be ascribed to exchange of the central hydrogens for deuterium atoms and to a reductive process in which two deuterium atoms are added.

The product-ion spectra of the $[\mathrm{M}+2 \mathrm{H}]^{+}$and $[(\mathrm{M}-$ $2 \mathrm{H}+2 \mathrm{D})+2 \mathrm{D}]^{+}$ions, acquired in the same experimental conditions, ${ }^{\circ}$ are ${ }^{\circ}$ similar ${ }^{\circ}$ for ${ }^{\circ}$ ll $^{\text {the }} \mathrm{e}^{\circ}$ compounds. In Table 3 the main product ions of the precursor ions $[\mathrm{M}+2 \mathrm{H}]^{+}$ and $[(M-2 H+2 D)+2 D]^{+}$ions, for compound 5, are presented. The data were acquired using methanol and deuterated methanol as the eluents, for solutions with concentrations $3.5 \times 10^{-6} \mathrm{M}$ and flow rates $5 \mu \mathrm{L} \mathrm{min}{ }^{-1}$, at a cone voltage of $30 \mathrm{~V}$ and collision energy of $45 \mathrm{eV}$.

As was described above the most abundant product ions are formed by the loss of two methyl groups and the second most abundant are the ions formed by loss of one methyl group. Ions formed by loss of two methyl groups and a HF molecule are also present. The presence of the triply charged species at $\mathrm{m} / \mathrm{z} 250.75$ and 251.46, which are the $\mathrm{M}^{3+}$ and $[\mathrm{M}-2 \mathrm{H}+2 \mathrm{D}]^{3+}$ ions, respectively, reinforces the similarity of the fragmentation processes of the $[\mathrm{M}+2 \mathrm{H}]^{+}$and $[(\mathrm{M}-2 \mathrm{H}+2 \mathrm{D})+2 \mathrm{D}]^{+}$ ions and, consequently, of their structures.

For approximately the same concentrations the for-

Table 3. Product-ion spectra of the $[\mathrm{M}+2 \mathrm{H}]^{+}$and $[(\mathrm{M}-2 \mathrm{H}+2 \mathrm{D})+2 \mathrm{D}]^{+}$ions of compound 5

\begin{tabular}{|c|c|c|c|c|}
\hline \multirow[b]{2}{*}{ Peak Identification } & \multicolumn{2}{|c|}{ Compound 5 in $\mathrm{CH}_{3} \mathrm{OH}$} & \multicolumn{2}{|c|}{ Compound 5 in $\mathrm{CD}_{3} \mathrm{OD}$} \\
\hline & $m / z$ & R-A (\%) & $m / z$ & R-A (\%) \\
\hline Percursor ions $[M+2 H]^{+} /[(M-2 H+2 D)+2 D]^{+}$ & 754.28 & 3 & 758.41 & 15 \\
\hline$\left[(\mathrm{M}+2 \mathrm{H})-\mathrm{CH}_{3}\right]^{+} /\left[(\mathrm{M}-2 \mathrm{H}+2 \mathrm{D})+2 \mathrm{D}-\mathrm{CH}_{3}\right]^{+}$ & 739.27 & 15 & 743.38 & 52 \\
\hline$\left[(\mathrm{M}+2 \mathrm{H})-2 \mathrm{CH}_{3}\right]^{+} /\left[(\mathrm{M}-2 \mathrm{H}+2 \mathrm{D})+2 \mathrm{D}-2 \mathrm{CH}_{3}\right]^{+}$ & 724.24 & 100 & 728.36 & 100 \\
\hline$\left[(\mathrm{M}+2 \mathrm{H})-3 \mathrm{CH}_{3}\right]^{+} /\left[(\mathrm{M}-2 \mathrm{H}+2 \mathrm{D})+2 \mathrm{D}-3 \mathrm{CH}_{3}\right]^{+}$ & 709.21 & 6 & 713.33 & 4 \\
\hline$\left[(\mathrm{M}+2 \mathrm{H})-2 \mathrm{CH}_{3}\right]^{+} /\left[(\mathrm{M}-2 \mathrm{H}+2 \mathrm{D})+2 \mathrm{D}-\mathrm{HF}-2 \mathrm{CH}_{3}\right]^{+}$ & 704.23 & 16 & 708.35 & 10 \\
\hline $\mathrm{M}^{3+} /[\mathrm{M}-2 \mathrm{H}+2 \mathrm{D}]^{3+}$ & 250.75 & 5 & 251.46 & 4 \\
\hline
\end{tabular}


mation of the reduced species does not increase significantly with the addition of an electron-donating compound such as $N, N$ dimethylaniline, and remains also approximately the same for the solvents used (except for the absence of the $[\mathrm{M}+2 \mathrm{H}]^{+}$ions in the case of acetonitrile). Taking these facts into account the sources of the electrons responsible for the reduction of the $\mathrm{M}^{3+}$ to the $\mathrm{M}^{2+}$ and $\mathrm{M}^{+}$ions are probably the iodide $\left(\mathrm{I}^{-}\right)$ counter ions. Although in the experimental conditions used, the formation of aggregates such as $\left[\mathrm{M}^{3+}+2 \mathrm{I}^{-}\right]$ and $\left[\mathrm{M}^{3+}+\mathrm{I}^{-}\right]$was not detected, the $\mathrm{M}^{+}$and $\mathrm{M}^{2+}$ ions may result of electron transfer, in counter ion/solvent clusters, from the iodide anions.

If we assume that such clusters are formed upon solvation, in a similar way as was described for dicationic $^{\circ}$ analytes ${ }^{\circ}[35]^{\circ}$, subsequent $^{\circ}$ electron $^{\circ}$ transfer $^{\circ}$ from the iodides would lead to the formation of the reduced species $\mathrm{M}^{+}$and $\mathrm{M}^{2+}$. These clusters would exist in the $^{\circ}$ droplets $^{\circ}$ as $^{\circ}$ tight $^{\circ}$ solvated $^{\circ}$ ion $^{\circ}$ pairs $^{\circ}$ [11], $\left[\mathrm{M}^{3+}+2 \mathrm{I}^{-}+n\left(\mathrm{CH}_{3} \mathrm{OH}\right)\right]$ and $\left[\mathrm{M}^{3+}+\mathrm{I}^{-}+n\left(\mathrm{CH}_{3} \mathrm{OH}\right)\right]$ and the reduction may occur while these aggregates are still in the relatively high-pressure regions of the source [36].

It is thus probable that the formation of the $\mathrm{M}^{+}$and $\mathrm{M}^{2+}$ ions may occur within the cluster, without change of the overall charge, as indicated below:

$$
\left[\mathrm{M}^{3+}+2 \mathrm{I}^{-}+\mathrm{n}\left(\mathrm{CH}_{3} \mathrm{OH}\right)\right] \rightarrow\left[\mathrm{M}^{+}+\mathrm{I}_{2}+\mathrm{n}\left(\mathrm{CH}_{3} \mathrm{OH}\right)\right]
$$

$$
\left[2 \mathrm{M}^{3+}+2 \mathrm{I}^{-}+\mathrm{n}\left(\mathrm{CH}_{3} \mathrm{OH}\right)\right] \rightarrow\left[2 \mathrm{M}^{2+}+\mathrm{I}_{2}+\mathrm{n}\left(\mathrm{CH}_{3} \mathrm{OH}\right)\right]
$$

The increase of the abundance of the $[\mathrm{M}+2 \mathrm{H}]^{+}$for lower flow rates and the formation of the [(M$2 \mathrm{H}+2 \mathrm{D})+2 \mathrm{D}]^{+}$ions in deuterated methanol confirms the important role of the solvent in the formation of the chlorin cations. Possibly their formation occurs within ${ }^{\circ}$ loose $^{\circ}$ ion $^{\circ}$ pair $^{\circ}$ clusters $^{\circ}[11]^{\circ}$ such $^{\circ}$ as $\left[\mathrm{M}^{3+}+n\left(\mathrm{CH}_{3} \mathrm{OH}\right)+2 \mathrm{I}^{-}\right]$and $\left[\mathrm{M}^{3+}+n\left(\mathrm{CH}_{3} \mathrm{OH}\right)+\mathrm{I}^{-}\right]$, in which the ions are separated by solvent molecules. Transfer of electrons, molecular fragments, and even protons within cluster ions have been reported for clusters ${ }^{\circ}$ of $^{\circ}$ metal $^{\circ}$ cations $^{\circ}$ and ${ }^{\circ}$ aprotic ${ }^{\circ}$ solvents ${ }^{\circ}[37] .{ }^{\circ}$ The occurrence of proton transfer is thus much more probable in the present case, given that methanol is a protic solvent. If loose clusters of large organic cations, such as porphyrins, are formed when methanol is used, both proton and electron transfer from the solvent may occur.

The fact that the reduced species $[\mathrm{M}+2 \mathrm{H}]^{+}$is formed with higher abundances when lower solvent flow rates are used is consistent with the first step of the overall reduction process being a protonation reaction. Decrease in the solution $\mathrm{pH}$, in positive-mode electrospray mass spectrometry, caused by solvent oxidation reactions in the needle, was reported, this decrease being higher $^{\circ}$ when $^{\circ}$ flow $^{\circ}$ rates $^{\circ}$ were $^{\circ}$ lower $^{\circ}[38]^{\circ}{ }^{\circ}$ Thus, $^{\circ}$ if $^{\circ}$ we assume that methanol can be oxidized in the needle, protons, formed as products of this oxidation, would be available in solution. More protons would then be produced when lower flow rates would be used and the extent of chlorin formation would be higher. The source of the electrons may be either the iodide counter ions or methoxide ions formed in the clusters by deprotonation of methanol.

\section{References}

1. Blades, A. T.; Ikonomou, M. G.; Kebarle, P. Mechanism of Electrospray Mass Spectrometry. Electrospray as an Electroysis Cell. Anal. Chem. 1991, 63, 2109-2114.

2. Van Berkel, G. J. The Electrolytic Nature of Electrospray. In Electrospray Ionization Mass Spectrometry: Fundamentals, Instrumentation, and Applications, Cole, R. B., Ed.; John Wiley \& Sons: New York, 1997; p 65.

3. De la Mora, J. F.; Van Berkel, G. J.; Enke, C. G.; Cole, R. B.; MartinezSanchez, M.; Fenn, J. B. Electrochemical Processes in Electrospray Ionization Mass Spectrometry. J. Mass Spectrom. 2000, 35, 939-952.

4. Van Berkel, G. J.; McLuckey, S. A.; Glish, G. L. Electrospray Ionization of Porphyrins Using a Quadrupole Ion Trap for Mass Analysis. Anal. Chem. 1991, 63, 1098-1109.

5. Van Berkel, G. J.; Zhou, F. Characterization of an Electrospray Ion Source as a Controlled-Current Electrolytic Cell. Anal. Chem. 1995, 67, 2916-2923.

6. Van Berkel, G. J.; Zhou, F. Observation of Gas-Phase Molecular Dications Formed from Neutral Organics in Solution via the ControlledCurrent Electrolytic Process Inherent to Electrospray. J. Am. Soc. Mass Spectrom. 1996, 7, 157-162.

7. Van Berkel, G. J.; Quirke, J. M. E.; Tigani, R. A.; Dilley, A. S.; Covey, T. R. Derivatization for Electrospray Mass Spectrometry. 3. Electrochemically Ionizable Derivatives. Anal. Chem. 1998, 70, 1544-1554.

8. Van Berkel, G. J. Insights into Analyte Electrolysis in an Electrospray Emitter from Chronopotentiometry Experiments and Mass Transport Calculations. J. Am. Soc. Mass Spectrom. 2000, 11, 951-960.

9. Rohner, T. C.; Lion, N.; Girault, H. H. Electrochemical and Theoretical Aspects of Electrospray Ionisation. Phys. Chem. Chem. Phys. 2004, 6, 3056-3058.

10. Diehl, G.; Karst, U. On-line Electrochemistry-MS and Related Techniques. Anal. Bioanal. Chem. 2002, 373, 390-398.

11. Milman, B. L. Cluster Ions of Diquat and Paraquat in Electrospray Mass Spectra and their Collision-induced Dissociation Spectra. Rapid Commun. Mass Spectrom. 2003, 17, 1344-1349.

12. Song, X.; Budde, W. Capillary Electrophoresis-Electrospray Mass Spectra of the Herbicides Paraquat and Diquat. J. Am. Soc. Mass Spectrom. 1996, 7, 981-986.

13. Moyano, E.; Games, D. E.; Galceran, M. T. Determination of Quaternary Ammonium Herbicides by Capillary Electrophoresis/Mass Spectrometry. Rapid Commun. Mass Spectrom. 1996, 10, 1379-1385.

14. Bigey, P.; Frau, S.; Loup, C.; Claparols, C.; Bernadou, J.; Meunier, B. Preparation and Characterization by Electrospray Mass Spectrometry of Cationic Metalloporphyrin DNA Cleavers. Bull. Soc. Chim. Fr. 1996, 133, $679-689$.

15. Batinic-Haberle, I.; Stevens, R. D.; Fridovich, I. Electrospray Mass Spectrometry of Isomeric Tetrakis(N-alkylpyridyl)porphyrins and Their Manganese(III) and Iron(III) Complexes. J. Porphyrins Phthalocyanins 2000, 4, 217-227.

16. Kachadourian, R.; Srinivasan, N.; Haney, C. A.; Stevens, R. D. An LDI-TOF and ESI Mass Spectrometry Study of a Series of beta-Substituted Cationic Metalloporphyrins. J. Porphyrins Phthalocyanins 2001, 5, 507-511.

17. Batinic-Haberle I.; Spasojevic, I.; Stevens, R. D.; Hambright, P.; Fridovich, I. Manganese(III) meso-Terakis(ortho-N-alkylpyridyl)porphyrins. Synthesis, Characterization and Catalysis of $\mathrm{O}_{2}^{-}$Dismutation. J. Chem. Soc. Dalton Trans. 2002, 2689-2696.

18. Cerny, R. L.; Gross, M. L. Abundances of Molecular Ion Species Desorbed by Fast Atom Bombardment: Observation of $(\mathrm{M}+2 \mathrm{H})^{+}$and $(\mathrm{M}+3 \mathrm{H})^{+}$. Anal. Chem. 1985, 57, 1160-1163.

19. Musselman, B. D.; Watson, J. T. Observation of Solvent Effects on Abundance of Polyhydrogen Adducts $(\mathrm{M}+\mathrm{nH})^{+}$in Fast Atom Bombardment Mass Spectrometry. Biomed. Environ. Mass Spectrom. 1987, 14, 247-248.

20. Vekey, K. Interference Effects Caused by Oxidation and Reduction Processes in Fast Atom Bombardment Mass-Spectrometry. Int. J. Mass Spectrom. Ion Proc. 1990, 97, 265-282.

21. Ohashi, Y.; Itoh, I. Unprecedented Matrix Induced Reduction of Flavins Observed under FAB and MALDI Conditions. Curr. Org. Chem. 2003, 7, 1605-1611.

22. Lindsey, J. S. Synthesis of meso-Substituted Porphyrins. In The Porphyrin Handbook-Synthesis and Organic Chemistry, vol. 1, Kadish, K. M.; Smith, K. M.; Guilard, R., Eds.; Academic Press: London, UK, 2000; p 45.

23. Tomé, J. P. C.; Neves, M. G. P. M. S.; Tomé, A. C.; Cavaleiro, J. A. S.; Soncin, M.; Magaraggia, M.; Ferro, S.; Jori, G. Synthesis and Antibacterial Activity of New Poly-S-lysine-Porphyrin. J. Med. Chem. 2004, 47, $6649-6652$. 
24. Tomé, J. P. C.; Mendonça, A. F.; Neves, M. G. P. M. S.; Tomé, A. C.; Valdeira, M. L.; Cavaleiro, J. A. S. PT Patent 2001, 102, 572.

25. Ryan, T. M.; Day, R. J.; Cooks, R. G. Secondary Ion Mass-Spectra of Diquaternary Ammonium-Salts. Anal. Chem. 1980, 52, 2054-2057.

26. Vincze, A.; Busch, K. L.; Cooks, R. G. Secondary Ion Mass-Spectra of Quaternary Pyridine Aldoximes. Anal. Chim. Acta 1982, 136, 143-153.

27. Heller, D. N.; Yergey, J.; Cotter, R. J. Doubly Charged Ions in Desorption Mass Spectrometry. Anal. Chem. 1983, 55, 1310-1313.

28. Clayton, E.; Wakefield, A. J. C. Fast Atom Bombardment (F.A.B.) Mass Spectrometry; Mechanism of Ionisation. J. Chem. Soc. Chem. Commun. 1984, 969-970.

29. Claereboudt, J.; Baeten, W.; Geise, H.; Claeys, M. Structural Characterization of Mono- and Bisphosphonium Salts by Fast Atom Bombardment Mass Spectrometry and Tandem Mass Spectrometry. Org. Mass Spectrom. 1993, 28, 71-82.

30. Kunkel, G. J.; Busch, K. L.; Dunphy, R.; Burinsky, D. J.; Barak, R.; Bel, P.; Amitai, G.; Vincze, A. Liquid Secondary Ion Mass Spectra and Fast Atom Bombardment Mass Spectra of Diquaternary Pyridinium Oxime Salts. J. Mass Spectrom. 1995, 30, 282-290.

31. Marr, J. C.; King, J. B. A Simple High Performance Liquid Chromatography/ Ionspray Tandem Mass Spectrometry Method for the Direct Determination of Paraquat and Diquat in Water. Rapid Commun. Mass Spectrom. 1997, 11, 479-483.
32. Lazar, A. C.; Reilly, P. T. A.; Whitten, W. B.; Ramsey, J. M. Laser Desorption/Ionization Coupled to Mass Spectrometry for Real-time Monitoring of Paraquat on the Surface of Environmental Particles. Rapid Commun. Mass Spectrom. 2000, 14, 1523-1529.

33. Smith, K. M. Porphyrins and Metalloporphyrins, Elsevier Scientific: Amsterdam, The Netherlands, 1975; pp 19-27.

34. Hashimoto, T.; Choe, Y.-K.; Nakano, H.; Hirao, K. Theoretical Study of the $\mathrm{Q}$ and $\mathrm{B}$ Bands of Free-base, Magnesium and Zinc Porphyrins and Their Derivatives. J. Phys. Chem. 1999, 103, 1894-1904.

35. Wang, G.; Cole, R. B. Effects of Solvent and Counterion on Ion Pairing and Observed Charge States of Diquaternary Ammonium Salts in Electrospray Mass Spectrometry. J. Am. Soc. Mass Spectrom. 1996, 7, 1050-1058.

36. Christie, C. G. A Predictive Model for Matrix and Analyte Effects in Electrospray Ionization of Singly Charged Analytes. Anal. Chem. 1997, 69, 4885-4893.

37. Shvartsburg, A. A. Acetonitrile Complexes of Triply Charged Metal Ions: Are Ligated Trications Intrinsically More Prone to Charge Reduction than Dications? Chem. Phys. Lett. 2002, 360, 479-486.

38. Van Berkel, G. J.; Zhou, F.; Aronson, J. T. Changes in Bulk Solution pH Caused by the Inherent Controlled-Current Electrolytic Process of an Electrospray Ion Source. Int. J. Mass Spectrom. Ion. Proc. 1997, 162, 55-67. 